\title{
SHOES IN BUDDHIST MONASTERIES FROM INDIA TO CHINA: FROM PRACTICAL ATTIRE TO SYMBOL
}

\author{
ANN HEIRMAN \\ Chinese Language and Culture, Ghent University \\ Blandijnberg 2, B9000 Ghent, Belgium \\ e-mail: Ann.Heirman@UGent.be
}

One of the most visible identity markers of Buddhist monasticism is clothing. The robes of monks and nuns have been paid considerable attention by researchers. By contrast, other pieces of monastic clothing have attracted far less attention, and this is particularly the case with footwear. Although shoes certainly play a secondary role compared to robes, they still present the monastic community with a number of complex issues. Shoes touch the ground, so they inevitably get dirty. Hence, wearing shoes could be considered disrespectful when meeting someone or paying homage, but so could showing one's naked feet. Meanwhile, shoes protect the feet from dirt and injury on difficult roads, so they may be viewed as essential attire. Additional issues relate to the material and the shape of the footwear, and which shoes are the most appropriate in various situations. This study discusses early Buddhist disciplinary (vinaya) texts' guidelines on issues relating to footwear, and explores how these guidelines were later received within China. It also provides a detailed picture of early Indian and Chinese Buddhist communities' attitudes to shoes, a problematic element of monastic clothing.

Key words: Buddhist monastic footwear, Buddhist monks, vinaya, Buddhist guidelines.

\section{Introduction}

When discussing monastic clothing, most attention is paid to the robes which are correctly identified as one of the primary visual identity markers of Buddhist monasticism. ${ }^{1}$ This identity is overtly displayed to the lay community, turning the monks' and nuns' clothes into sensitive artefacts that are constantly exposed to social conventions. Monks need to be acknowledged both as Buddhist monks and as people who merit respect and gifts. As Schopen (1997, p. 70) explains, "to be accepted as a Bud-

\footnotetext{
${ }^{1}$ See, among others, Kieschnick (1999; 2003, pp. 86-107) and Heirman (2014).
} 
dhist monk, one must not present in public an unkempt appearance nor be seen in disreputable robes".

The present study focuses on this notion of "unkempt appearance". Yet, it diverts attention away from the robes and towards an often neglected component of the monastic clothing set: the footwear. As we will see, shoes are also important markers of Buddhist identity, evoking reactions in both monastic and lay communities. So what does "disreputable" imply when referring to shoes? Is it acceptable to wear them at all? If it is, which shoes should be worn in which situations? And how should one care for one's shoes? These and other questions have been important issues for members of various monastic communities whenever they have sought to interrelate in a socially acceptable way with their fellow monastics or with their neighbours in the lay community.

We focus on a crucial time for monastic Buddhism in East Asia: the era when Indian Buddhist disciplinary guidelines were exported to China. The significance of the new context should not be underestimated. Conditions obviously vary through time and space, and Chinese masters who referred to India as a source of authoritative inspiration were certainly aware of this, as they studied and discussed at length how the Indian guidelines should be implemented. ${ }^{2}$

Given the importance of a proper dress code, it is unsurprising that every Buddhist community tried to offer their members advice on how to deal with footwear. The basic guidelines can be found in vinayas (disciplinary texts), of which six full sets have survived to this day, although most of them were written in Chinese. These are the Pāli vinaya (extant only in the Pāli language) and, in chronological order of translation into Chinese: the Shisong lü 十誦律 (T.1435; Sarvāstivādavinaya); the Sifen lü 四分律 (T.1428; Dharmaguptakavinaya); the Mohesengqi lü 摩訶僧祇律 (T.1425; Mahāsāmghikavinaya); the Mishasai bu hexi wufen lü 彌沙塞部和醘五分 律 (T.1421; Mahìśsasakavinaya); and the Genbenshuoyiqieyou bu pinaiye 根本說一 切有部毘奈耶 (TT.1442-1451; Mülasarvāstivādavinaya). ${ }^{3}$ The Sarvāstivādavinaya, Dharmaguptakavinaya, Mahāsāmghikavinaya and Mahīśāsakavinaya were all translated in the 5th century $\mathrm{AD}$, while the Mülasarvāstivādavinaya was translated in the 8th century. Guidelines on shoes are scattered throughout these texts, but it is striking that these vinayas also devote a full chapter solely to footwear, emphasising the topic's importance. 4

Chinese masters viewed the Indian vinayas as authoritative sources that could help their communities to present themselves as authentically Buddhist. In this sense, the early 5th-century vinaya translations constituted both rich and inspiring documents, but they also presented a problem. Although the various vinaya texts are similar in many respects, they certainly do not agree on all matters, and such inconsistencies must have made life difficult for monastic masters who were looking for a stand-

\footnotetext{
${ }^{2}$ For a discussion, see Heirman and Torck (2012, pp. 3-5).

${ }^{3}$ For details on the translation of these vinaya traditions, see Yuyama (1979) and Heirman (2007, pp. 175-181). A Tibetan translation of the Mūlasarvāstivādavinaya and substantial Sanskrit sections have survived.

${ }^{4}$ For a general overview, see Frauwallner (1956, pp. 88-91).
} 
ard to follow. Discussions arose, and eventually several influential Buddhist masters, such as Daoxuan 道宣 (596-667), singled out the Dharmaguptakavinaya as the paramount vinaya for Chinese Buddhists. Then, around 705-710, it was decided by imperial decree that this vinaya - and it alone - should be used for ordinations in the Chinese empire. ${ }^{5}$ The Dharmaguptakavinaya thus became the dominant reference point for all monastic discipline in China. However, this does not mean that we should ignore the other vinayas. Daoxuan studied every vinaya translation that was available at the time, and although he stressed that the Dharmaguptakavinaya was foremost among them, he urged his followers to consult the others when necessary (T.1804: 2b19-20). Therefore, I will follow the Chinese masters' lead by focusing on the Dharmaguptakavinaya while including any significant comments and guidelines from the other vinayas.

It is also important to note that guidelines made in one historical and geographical context cannot be transposed wholesale to a new setting. Consequently, it is unsurprising that the vinayas were widely debated in China after the translation of the first four in the 5th century. The Chinese vinaya commentaries thus constitute rich sources of information on how daily life - and especially, in the context of this research, footwear - was perceived by Chinese Buddhists. Furthermore, in these new Chinese settings, masters started to write their own manuals in order to provide guidance for new members of their communities. Some even embarked on educational visits to India and subsequently related their experiences to their fellow monks back home in China.

All of these diverse sources provide us with very rich details of daily life in mediaeval China - or at least details of how the Buddhist communities perceived daily life. As I recently discussed in a study on monastic bodily care (Heirman-Torck 2012, pp. 10-13), it would be wrong to consider vinaya texts, commentaries, manuals or even travel reports as eyewitness accounts by Buddhist authors, or as academic studies on Buddhist life. They were all written with a normative aim, and therefore provide insights into how Buddhist monastics felt that they and their fellow monks should ideally behave. Still, all of these texts also mention objects, ideas and practices with which the compilers/authors and their readers must have been familiar. ${ }^{6}$ In this sense, in addition to presenting an ideal normative monastic setting, identifying the Buddhist community, they provide valuable information on the material culture that was prevalent in the contexts where they were written.

In the first part of this paper I will investigate the Indian vinayas' guidelines on the use of footwear. What was allowed and why? Which practices were seen as acceptable and which were prohibited? And what motivated the compilers to draft these rules? Following this discussion, I will explore how the Chinese vinaya masters interpreted the Indian guidelines, and investigate which practices they viewed as appropriate for the Chinese monastic community.

\footnotetext{
${ }^{5}$ See, among others, Funayama (2004, pp. 113-115) and Heirman (2007, pp. 192-195).

${ }^{6}$ For a discussion, see among others, Nattier (2003, pp. 63-69) and Clarke (2014, pp. 29-36).
} 


\section{Footwear Guidelines in Vinaya Texts}

\subsection{What Kind of Footwear Is Allowed and What Is Prohibited?}

The vinaya texts include several words for footwear. In the Chinese translations the most commonly used term is gexi 革屣, while in the Pāli vinaya it is upāhanā. The Chinese term ge refers to the use of leather - a material that every vinaya explicitly permits for footwear, albeit with several restrictions. ${ }^{7}$ For instance, leather fashioned from the hides of large animals, such as lions, tigers or foxes, may not be used for any purpose, except to wrap a knife (Dharmaguptakavinaya, T.1428: 846b13-15 and c25-27). ${ }^{8}$ Hence, it may not be used in the edges or straps of a shoe (T.1428: 847a1418). Moreover, the leather that is used must be well tanned. A monk may do this himself if he is suitably skilled, or he may ask lay people to do it for him (T.1428: 846a17-18).

Aside from gexi, the Chinese vinaya translations include several other terms for footwear. However, it is often difficult to know what was exactly meant by these words, and indeed what the articles in question looked like. The Dharmaguptavinaya (T.1428: 846c28-29), for instance, forbids the use of jiana fuluo gexi 迦那富羅革 履, unless the monk is walking on very thorny roads, when they may be worn to protect the feet from injury (T.1428: 846c29-847a4). While the meaning of jiana remains unclear, fuluo is a known transliteration of the Buddhist Sanskrit term pülaa short boot. ${ }^{9}$ Such boots are allowed, for example, in the Mahīśāsakavinaya to prevent foot injuries (T.1421: 146c12-18). The Chinese terms used in this Mahiśsassakavinaya passage are fuluo 富羅 and yong 韄, the latter being a rather rare word that refers to the leg of a boot. When lay people complain that these boots are very long and therefore resemble their own boots (xue 靴), the Buddha states that the monks' boots can reach just above the ankle but no higher, and that they should be open at the front. The same passage from the Mahissäsakavinaya allows boots (fuluo) when a monk is travelling in very cold and snowy regions, to prevent freezing of the feet. If, notwithstanding the boots, there is still a risk of frozen feet, a monk may add a

${ }^{7}$ The Mūlasarvāstvādavinaya (T.1447: 1057b3-9) contains a brief passage which explains that leather (in this case fashioned from bear's skin) is acceptable if it is offered to the samgha without any thought of killing and instead with a faithful heart.

${ }^{8}$ No reason is given for these guidelines, but it is reasonable to suggest that the prohibition is an extension of the rules relating to eating the meat of large animals. The latter practice is prohibited on the grounds that the animals involved, knowing that they might be eaten, might start to attack members of the monastic community. Other animals, such as elephants or horses, may not be eaten because they are used by rulers. See Kieschnick (2005, pp. 188-189) and Heirman - De Rauw (2006, pp. 60-61). On the issue of the dangers of using leather, the Mahiśāsakavinaya (T.1421: $147 \mathrm{a} 5-7)$ relates a story about monks sitting and sleeping on leather items. Evil beasts smelled it and killed the monks.

${ }^{9}$ Nakamura (1985, p. 1179, s.v. 富羅). The Dharmaguptakavinaya (T.1428: 711a9-12) uses the term fuluo when forbidding the wearing of shoes (gexi and fuluo) in the neighbourhood of a stūpa (see below). 
layer of soft butter or bear's grease, or fashion his boots ( $x u e$ 靴) out of bear's skin. ${ }^{10}$ Other vinayas refer to cold regions, too: for instance, the Dharmaguptakvinaya says that when visiting a very cold place where there is a risk of frozen feet, a monk is allowed to wear boots (fuluo andi 富羅菴鞮) ${ }^{11}$ and socks (mo 䪄) (T.1428: 849a2328).

Another kind of footwear mentioned in the vinayas is xie 㞜, a kind of sandal. The Mahisisāsakavinaya (T.1421: 146b29-c1) describes it as a sandal made out of various kinds of straw. This makes it vulnerable to water that can easily soak in; so a rawhide, leather or bark sole may be added (Mahiśāsakavinaya, T.1421: 146c1-3; Dharmaguptakavinaya, T.1428: 771a4-7). A last kind of footwear mentioned are wooden clogs ( $m u$ ji木屐), prohibited under normal circumstances, although they may be worn in toilet facilities and washing places (Dharmaguptakavinaya, T.1428: 847 b11-12, b17-21).

Shoes must always be simple to symbolise the humble life of a monk. In fact, wearing no shoes at all would be an even stronger sign of a modest life. Nevertheless, the Buddha permits the wearing of shoes, particularly inside the monastery. The story behind this guideline is usually connected to the monk Sronakotịvimśa, one of the Buddha's most zealous disciples (Dharmaguptakavinaya, T.1428: 845a15-28). Having lived in heaven for a very long time, he is not used to walking on hard earth, so the Buddha allows him to wear shoes. Still, the monk has doubts, thinking that people will view him as greedy (tan 貪) and longing for the luxury of shoes with soles. He therefore requests that all monks - not just himself - should be allowed to wear such shoes. The Buddha replies that, on the one hand, monks should be content with very little, but, on the other hand, they can wear shoes with soles to prevent soiling their bodies, clothes and sleeping material. Also, if shoes wear out quickly, and develop holes in the sole, the Buddha permits repairs using bark or leather. If the sole breaks off altogether, tendons, wool or leather thread may be used to sew it, utilising several instruments, such as a knife and an awl (T.1428: 846a18-22). However, each shoe may not have more than one sole (T.1428: 846c27-28), because multisoled shoes are very valuable (you guijia 有貴價) and are therefore unsuitable for monks (T.1428: 849a14-18). ${ }^{12}$ Notwithstanding this stipulation, more soles may be added in places where the roads are particularly thorny and covered in stones, as this follows the custom of the people who live in such regions (T.1428: 845b29-c2, 846a10-11). ${ }^{13}$ This shows how the vinaya texts sometimes take local requirements

${ }^{10}$ Monks may also use bear's grease, or wrap their heels with bear's skin, when suffering from cracked heels (Mahisiśasakavinaya, T.1421: 146c11-12). See also Mahisísasakavinaya (T.1421: 146c21-29), a passage that generally advocates adapting to local footwear customs, if necessary.

${ }^{11}$ This transliterated term remains partially unclear. The first part is a transliteration of pūla - boots. The Sarvāstvādavinaya and the Mülasarvāstvādavinaya allow the wearing of xue 鞾 (boots; T.1435: 414c5) or fuluo 富羅 (T.1447: 1057a29-b1) in cold regions.

${ }^{12}$ The Dharmaguptakavinaya allows an exception for shoes taken from a graveyard (T.1428: 849a15-18). For a discussion on clothing taken from graveyards, see, in particular, Witkowski (2013).

${ }^{13}$ The Sarvāstvādavinaya (T.1435: 183b2-3,183b29-c1) and the Mūlasarvāstvādavinaya (T.1447: 1056a10-12) similarly allow monks to wear shoes with single soles. In addition, they 
and habits into consideration. Similarly, some flexibility is often displayed on matters relating to medical conditions: for instance, elderly monks with weak feet may use shoes with covered heels; and monks who are visually impaired are permitted to wear shoes that cover the front of the feet and the toes (T.1428: 848b17-21).

In sum, it is apparent that, although the use of shoes is strictly prescribed, the vinayas acknowledge that many practical issues need to be considered, and they provide detailed explanations for why shoes may - or indeed should - be worn in such circumstances. As we will see below, these explanations are a rich source of information on how monks should behave in order to act as proper representatives of the Buddhist community in a social context. Moreover, they give some insight into the material culture relating to footwear as displayed by the vinaya texts.

\subsection{Wearing Shoes Is Impolite}

The vinaya texts frequently indicate that it is polite to remove one's shoes when greeting someone. A common formulation is as follows (Dharmaguptakavinaya, T.1428: 605a27-28): "one should go to the samgha, uncover the right shoulder, take off the shoes (gexi 革履) and honour the seniors; one should put the right knee on the ground and join the palms". "Honouring seniors" often involves touching their feet, as is implied, for instance, in the Dharmaguptakavinaya (T.1428: 632c13): "one honours the feet of the seniors". ${ }^{15}$ Even more explicit is the following passage from the Mahiśäsakavinaya (T.1421: 110c29-111a1): "in accordance with the rules of the upādhyā$y a$ (teacher), one should uncover the right shoulder, take off the shoes, kneel down and with both hands hold the feet of the upādhyaya".

A Mahiśásakavinaya guideline (T.1421: 180a19-24) is interesting in this context as it strongly suggests that removing one's shoes is a sign of respect. The guideline goes as follows: if, on the road, a thief asks a monk for water, the monk should take off his shoes, wash his hands and offer the thief a drink (maybe to protect himself). A similar procedure should be followed when a lay follower asks for water.

refer to regions where the roads are very stony. Surprisingly, though, and in contrast to the Dharmaguptakavinaya, the Sarvāstvādavinaya (T.1435: 181a25-27, 181c19-21, 182a5-6, 414c4-5) and the Mülasarvāstvādavinaya (T.1447: 1053a2-5) do not soften their line on the number of soles that may be used when walking on tough roads. Instead, they both state that shoes with one sole are permitted in such places. Consequently, exactly the same shoes are allowed on well-maintained and poor roads. These somewhat conflicting guidelines might be the result of unfinished editorial work.

${ }^{14}$ The Chinese vinayas use two expressions to refer to "kneeling down": hu gui 胡跪 ('foreign kneeling down') and you xi zhu di 右膝著地 ('putting one's right knee on the ground'). As mentioned in Ciyi (1989, p. 3939, s.v. 胡跍), it is commonly said that the true meaning of $h u$ gui remains unclear: either both knees touching the ground, or just the right knee touching the ground. Yet, given that the vinayas frequently interchange both expressions (see, for instance, Dharmaguptakavinaya, T.1428: 585b29: 右膝著地; and 586c12: 胡跍), it is logical to interpret $h u$ gui as putting only the right knee on the ground.

${ }^{15}$ An exception is allowed when a monk wishes to offer something to a teacher on the road. In such circumstances, the respectful but rather complex formal routine might exhaust the disciple, so he may hand his teacher an item in a more simple fashion (T.1428: 848a28-b4). 
However, if a non-Buddhist ascetic (wai dao 外道) requests water, the monk should follow this routine only if doing so will benefit the Buddhist dharma. If no such benefit is likely, the monk should offer the ascetic water with both hands but keep his shoes on, in order that the ascetic does not conclude that the monk is paying him respect (gongjing 恭敬). In addition to showing what respect implies, this guideline reveals that the compilers of the vinaya took pains to distinguish themselves from the wai dao, and they were determined not to pay them any explicit respect. ${ }^{16}$

As discussed above, removing one's shoes is a primary sign of respect towards one's seniors. Similarly, both monks and lay people are expected to remove any footwear when listening to Buddhist teachings. For instance, a monk should not wear shoes when attending a ceremony, most notably the poșadha ${ }^{17}$ and the pravarana ${ }^{18}$ just as he should not wrap his robes around his neck or head during ceremonies (Dharmaguptakavinaya, T.1428: 836c27-837a10). The Mahīśāsakavinaya (T.1421: 128c9-12) castigates those who wear shoes in such situations as "not polite" (bu gongjing 不恭敬) and puts such behaviour on a par with lying down or leaning, standing with arms akimbo, covering the head, or wearing clothes in an untidy fashion. ${ }^{19}$ Given this, it is unsurprising that monks are not allowed to teach the dharma to anyone who wears (wooden) clogs ((mu) ji (木)屐) or leather shoes (gexi 革屣).

In all of the vinayas, this regulation is listed among the śaikșa rules - minor directives relating to proper behaviour. Anyone who transgresses it commits a duṣkta, "a bad deed". ${ }^{20}$ An exception is allowed only for listeners who are ill and cannot remove their shoes. Both the Mahīśāsakavinaya and the Mahāsāmghikavinaya declare that lay people, in particular, criticise monks who teach shoe-wearing listeners. This again indicates that the compilers of the vinayas were acutely conscious of the role of the Buddhist samgha in social life: monks had to earn respect for themselves, their community and the Buddhist dharma. The Mahiśāsakavinaya goes as far as to state that monks who show disrespect by wearing shoes demean (qing man 輕慢) the dharma. Meanwhile, the Mahāsāmghikavinaya warns that lay people compare shoe-wearing monks to performers and bad people to whom no respect (gongjing 恭敬) should be shown. In the Pāli vinaya, the Buddha himself reproaches such monks and states

\footnotetext{
${ }^{16}$ On this quite explicit rivalry, see the recent study by Claire Maes (2015, pp. 169-172).

${ }^{17}$ The prātimokșa (list of disciplinary rules) is recited during the poșadha ceremony, held every fortnight.

${ }^{18}$ Every monk invites his fellow monks to point out his errors - whether seen, heard or suspected - at the invitation ( pravāraña ) ceremony, held at the end of the rain season.

${ }^{19}$ The Mahiśsāsakavinaya (T.1421: 181b27-29) mentions guest monks' similarly improper behaviour in the presence of decent monks.

${ }^{20}$ Pāli vinaya (Vin, vol. 4, p. 201): pādukā (shoe, clog) and upāhanā (shoe, sandal); Mahīśāsakavinaya (T.1421: 76c15-77a1); Mahāsāmghikavinaya (T.1425: 408b29-409a9; this vinaya also lists some exceptions: there is no offence if the road is rough or some difficult circumstances prevent people from removing their shoes); Dharmaguptakavinaya (T.1428: 710b2-4); Sarvāstvādavinaya (T.1435: 140a20-27); Mūlasarvāstivādavinaya (T.1442: 904a5; this vinaya includes clogs, boots and sandals - ji xue xie ji lü ju 履靴鞋及履㞛 - in addition to “normal” shoes). In this context, the Mahis'sasakavinaya seems to be the most pragmatic vinaya. It adds that if many people are wearing shoes, and it is impossible to ask all of them to remove their footwear, then - in one's mind - one should preach the dharma to only those listeners who are barefoot.
} 
that they show no respect for the Buddhist teachings. Finally, the Dharmaguptakavinaya (T.1428: 710c18-711a12) cites the importance of showing respect when it explains that neither shoes (gexi 革屣) nor boots (fuluo 富羅, püla) may be worn when entering or circumambulating a stūpa of the Buddha. Similarly a monk should not carry his shoes in his hands when in the vicinity of these stūpas. ${ }^{21}$

\subsection{Shoes Are Dirty}

Clearly, then, removing one's shoes is an explicit sign of respect. The logic is obvious: shoes walk on dirty streets, so they accumulate dirt. In that sense, they symbolise uncleanliness, so bringing them into contact with other people signifies a lack of respect. On the other hand, they protect the wearer's feet from difficult roads and prevent the monk's body and robes from getting dirty. ${ }^{22}$ In both instances, the main concern remains cleanliness, as dirt is perceived as problematic: it shows a lack of respect and it is often associated with reduced value. Moreover, as we will discuss below, it is sometimes linked to impurity. ${ }^{23}$

There are also some problems relating to the use of leather. Although this material is allowed, the vinayas stress that it should be avoided if possible. Especially problematic is sitting on leather, which is explicitly forbidden, except in regions where this is the local custom (Dharmaguptakavinaya, T.1428: 846a27-28). Monks are said to be quite anxious about this: for instance, they are concerned about turning over in their sleep and coming to rest on the shoes that they have placed next to themselves. The Buddha reassures them that this is not the same as deliberately sitting on leather (T.1428: $846 \mathrm{~b} 2-4) .^{24}$

The connection between shoes, dirt, respect and impurity is particularly apparent when the vinayas discuss where removed shoes should be placed. The Buddha reprimands some monks who put their shoes in their begging bowls, and explains that the begging bowl should always be handled in a clean and pure way (qing jing 清淨) (T.1428: 846b4-6). That this guideline is concerned not only with dirt but also with respect and the importance of protecting such a powerful symbol as the begging bowl - the physical connection between lay followers and the monks as receivers of alms and sources of merit - is clear from the next guideline which states that shoes

${ }^{21}$ Similarly, T.1428: 957c25-958a1. This latter passage adds one more detail: it says that while one cannot enter a stüpa either wearing boots or holding them in one's hands, one may wear them when walking in the vicinity of a stüpa (presumably because boots are allowed in very cold weather). The Mahāsāmghikavinaya (T.1425: 498a15-18) warns that shoes should not be worn in the vicinity of a stūpa.

${ }^{22}$ In this context, the Dharmaguptakavinaya (T.1428: 846a26-27) warns that monks should not sit on shoes when wearing new clothes, to prevent the robes from getting dirty.

${ }^{23}$ On cleanliness of the body and purity of mind, see, in particular, Heirman - Torck (2012).

${ }^{24}$ A similar situation arises when monks stay at a potter's house and unwittingly sleep on leather (which has been used to cover the clay). On another occasion, monks cross a river on a boat with leather seats. The Buddha again reassures them in both instances (T.1428: 846b10-13, $846 \mathrm{c} 23-25)$. 
and begging bowls should not even be carried in the same hand (T.1428: 846b6-8). Nevertheless, as is quite common in the vinaya texts, the compilers also provided some ingenious solutions to potential problems. For instance, if a monk were to walk over mud and could not lift his robes because he was holding his shoes in one hand and his begging bowl in the other, his robes would get dirty. In such situations, the Buddha allows the monk to hold his shoes with his fingers and the begging bowl in the palm of the same hand, which allows him to lift his robes with the other hand (T.1428: 846b8-10). Maintaining the robes' cleanliness is therefore accorded higher priority than keeping shoes and begging bowl in separate hands. It is imperative to stop the robes dragging on the ground or touching dirty shoes. In addition to providing a pragmatic solution to a potentially problematic situation, this passage implicitly acknowledges that shoes can soil both the robes and the begging bowl. There is more to this than a simple, practical desire to maintain physical cleanliness: on a more abstract level, shoes can endanger the purity of the samgha and its members, as symbolised by the robes and the begging bowl. So they have the potential to degrade the samgha and, as we have seen above, demean the dharma. A dirty community can never offer a truly worthy dharma. Such a community deserves less respect and it is less capable of providing karmic benefits for its lay followers. This relationship between outward cleanliness and inner morality prompts the compilers of the vinayas to pay special attention to the cleanliness of the community, and leads to more regulations about shoes. ${ }^{25}$

The relationship between shoes, gifts for the samgha, purity and merit is perfectly illustrated by a passage from the Mahāsāmghikavinaya (T.1425: 481c29482a10). After the Buddha has declared that monks may wear shoes, a rich merchant, Anāthapiṇdada, offers him five hundred pairs. The Buddha accepts the gift and declares that when pure monks receive shoes, donors receive great merit in return. The donor offers a little - shoes - but gains a lot. The return is material as well as spiritual (T.1425: 482a5-10):

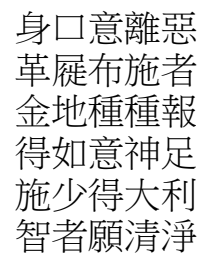

Body, speech and mind abandon evil Those who donate shoes

Golden ground and all kinds of return Supernatural powers as one wishes
清淨梵行人
人孚樂
莊嚴諸宫殿
清淨無障礙
清淨福田故
能得福田果

Pure people, with pure conduct

Will receive happiness among men and gods

Majestic palaces

Purity without hindrances

\footnotetext{
${ }^{25}$ In her work on virtuous bodies, Susanne Mrozik (2007, p. 62) uses the term "physiomoral discourse" to highlight the close relationship between the body and morality, the external and the internal. Here I extend this concept to artefacts that are closely linked to the body, such as robes and shoes.
} 

One donates a little and receives a lot Because of the pure field of merit (= monks)
The wise [donors] long for purity
And can obtain the fruits of the field of merit

\subsection{Shoes Are a Sign of Luxury and Frivolity}

Aside from potential associations with dirt, shoes can undermine the perception of the Buddhist community in a quite different way. Beautiful shoes may symbolise luxury and the higher echelons of society. So monastics' footwear should always be simple, and any hint of greed and personal longing for luxury is forbidden. Hence, shoes that are adorned with horns, straps of various colours or fashioned out of silk, ${ }^{26}$ peacock feathers or brocade are expressly prohibited (T.1428: 847a4-b26). The colours of the shoes themselves also feature in this list of improper footwear. Not permitted are a particular shade of blue-green (qing 青), yellow (huang 黃), red (chi 赤) and white (bai 白). ${ }^{27}$ In fact, only so-called "bad colours" (huai se 壤色) may be used. $^{28}$ Also forbidden are covered shoes, as these are associated with vanity. Monks who wear them are described as foolish people (chi ren 癡人). Shoes covered with down, cotton, silk or various grasses are therefore usually forbidden, as are woollen shoes. However, when there is rain and mud, and a risk that the feet, the body, and the sleeping and/or sitting material will get dirty, the Buddha allows monks to wear shoes made out of rushes ( $p u$ 蒲), with tree-bark undersides and leather seams. By contrast, leaves of the tâla tree may never be used because cutting these leaves causes the trees to wither, which in turn leads to criticism from the lay community (Dharmaguptakavinaya, T.1428: 847b12-17). ${ }^{29}$ This passage uses the term "cutting off life"

${ }^{26}$ Aside from perceiving it as a luxury product, the vinaya texts associate silk with killing (of silk worms). Its use is therefore criticised and restricted, although not forbidden. See, for instance, Dharmaguptakavinaya (T.1428: 613c25-614a26) which emphasises the suffering of boiled silkworms. For a discussion, see, among others, Liu (1996, pp. 50-52) and Young (2013, pp. 3940).

${ }^{27}$ The Pāli vinaya (Vin, vol. 1, p. 185) has another list of non-permissible colours, all of which are deemed inappropriate because they are worn by lay people. Horner (1938-1966, vol. 4, p. 246) translates these as entirely dark green, entirely yellow, entirely red, entirely crimson, entirely black, entirely orange and entirely multi-coloured. The Sarvāstvādavinaya (T.1435: 182a8-9, 183b5-6) lists the following prohibited colours: entirely dark green, yellow, red, white and black. It also forbids multi-coloured shoes (T.1435: 182a15, 183b11-12).

${ }^{28}$ Multi-coloured shoes, seen as luxury (zhuangyan 莊嚴) items, are not allowed (T.1428: 963a13-14). As I have shown elsewhere (Heirman 2014, pp. 475-477), "bad colours" have a lower status than "superior colours".

${ }^{29}$ As discussed by Lambert Schmithausen (2009), there is no conclusive evidence that plants were regarded as sentient beings in early Buddhism, although some passages seem to suggest this. Schmithausen argues that the matter remained unresolved in early Buddhism, while "there was a growing tendency toward an attitude of strong reserve against any explicit classification of plants as sentient beings in a doctrinal sense" (p. 98). Discussing Jain influence on early Buddhism, Richard Gombrich (2009, pp. 52-53) reaches a similar conclusion, while stating that the Buddha remained 
(duanjue shengming 斷絕生命) when referring to the damage that may be caused to these trees, which suggests that the rule was formulated specifically to avoid killing a living thing. Similar rules seem to have been devised for the same reason in other vinaya texts. ${ }^{30}$ Finally, the list excludes all kinds of luxury material, including precious metals and precious stones.

Luxury can also be expressed by the status of the shoes, so new shoes could be a sign of wealth, whereas used shoes symbolise modesty. Of course, this can create some problems when the laity offer monks new shoes. In such a situation, the Mahiśäsakavinaya (T.1421: 147a16-18) specifies that monks may accept new shoes only if a lay attendant (jing ren 淨人) ${ }^{31}$ first walks seven steps in them. ${ }^{32}$ The problem is solved by this symbolic act: the monk can accept the gift because the notion of living a simple life has been honoured. Still, the compilers of the vinayas sometimes struggle to define the subtle balance between luxury and inappropriate poverty. For instance, the Mahāsāmghikavinaya lacks consistency when advising on the number of soles that shoes may have. On the one hand, it is in line with the regulations found in other vinayas: shoes may have only one sole, except in certain regions (T.1425: 416a15$17,481 \mathrm{c} 29-482 \mathrm{a} 1)$. On the other hand, it contains a passage that seems to forbid the use of shoes with one sole (T.1425: 480c24-481a1). The narrative goes as follows: lay people criticise a group of monks for wearing a variety of luxury shoes, because this kind of footwear is associated with high officials. At the same time, however, the lay people also criticise some other monks for wearing single-soled shoes which are allegedly worn by mean and corrupt people (xia jian ren 下賤人 and huai bai ren 壞敗人). Such undesirables cannot possibly have anything valuable to teach the laity: he dao zhi you 何道之有, “which kind of teachings could they have?" Therefore, the Buddha forbids monks to wear shoes with one sole. His reasoning is that shoes with

intentionally ambiguous so as not to offend either members of the public or virtuous Buddhist monks.

${ }^{30}$ The Pāli vinaya (Vin, vol. 1, p. 189; Horner 1938-1966, vol. 4, pp. 251-252) states that lay people criticised monks for harming life that was single-facultied (ekindriya jiva). On this concept and its role in Buddhism, see Maes (2010-2011, p. 102) who argues that "the occurrence of ekindriya jīva in the Pāli vinaya should be understood as a remnant of an early inter-communal debate between Buddhists and Jains on the principle of non-violence towards one-sensed facultied beings". In the same Pāli vinaya passage, the Buddha further explains that people believe that there are living beings residing in palm trees (and in bamboo), so monks should not touch them. The latter explanation no longer takes the concept of single-facultied life into account.

${ }^{31}$ Lit. 'purifying person' (kalpikära) - a person who makes things suitable for monastics, for example by accepting gifts that monks are not allowed to accept.

${ }^{32}$ The Mahāsāmghikavinaya (T.1425: 482a22-24) contains a similar guideline, but mentions only five to six steps. Meanwhile, the Sarvāstvādavinaya (T.1435: 184a4-b12) refers to the help of a kind of kalpikāra, but the context is slightly different: when monks receive shoes with thick soles, which should not be worn by monastics (T.1435: 182a7, 183b3-4, 183c1), a lay person is asked to walk two or three steps in those shoes in order to purify them and make them permissible. The vinaya warns that this course of action is acceptable only for shoes with thick soles, not for other luxury footwear. Finally, the Mūlasarvāstvādavinaya (T.1447: 1056b2-c1) suggests asking lay donors who wish to offer shoes with multiple soles to walk in them for seven or eight steps, as this will allow the monks to accept "used" (as opposed to new) shoes. 
a single sole are inappropriately simple and so harm the respect that is due to the samgha.

Generally, the above regulations promote a simple, modest life, free from any desire but still socially appropriate. A further stipulation correlates with this notion: a monk should not wear shoes when entering a village (Dharmaguptakavinaya, T.1428: 848b5-17). Lay householders had criticised some monks who had kept their shoes on, emphasising that such behaviour goes against the Buddhist doctrine and comparing it to the conduct of kings and high officials. Hence, the Buddha forbids it. (An exception is allowed for monks who are seriously ill, with the implication being that a monk should not claim illness casually.) However, the Buddha allows shoes on roads between villages to minimise the risk of injury from thorns. Only when entering the village should the shoes be removed and put in a safe place. They can be put on again when leaving the village (T.1428: 849a14-15, 932c26-29, 933b7-8).

Finally, specifically for nuns, shoes are not only a sign of luxury but, in combination with umbrellas, symbolise frivolity - behaviour that is associated with prostitutes and thieves (Dharmaguptakavinaya, T.1428: 770c15-16). ${ }^{33}$ Therefore, nuns should refrain from wearing shoes and carrying an umbrella. Violation of this rule constitutes a pācittika offence. ${ }^{34}$ An exception is allowed, however, when there is a lot of rain and mud: shoes may be worn inside the monastery in order to protect the body, the clothes and the seating material (T.1428: 771a2-5). ${ }^{35}$

\subsection{Wearing Shoes among Monastics}

As shoes are associated with both dirt and luxury, and as a refusal to remove shoes when meeting people (and especially seniors) is seen as disrespectful, it is unsurprising that the wearing of shoes in a monastic context is strictly regulated. In the Dharmaguptakavinaya (T.1428: 847b27-c18) a group of shoe-wearing monks walk in meditation alongside the Buddha. The Buddha reacts by saying that disciples of wise nonBuddhist teachers show respect (gongjing 恭敬) towards their masters, implying that his own disciples are not displaying similar respect, and that some non-Buddhist

${ }^{33}$ Also mentioned in the Mahissāsakavinaya (T.1421: 94c7-8).

${ }^{34}$ A pācittika (or variants) is an offence that must be expiated (see Heirman 2002, pp. 141147). All vinayas have a similar rule: Pāli vinaya (Vin, vol. 4, pp. 337-338) (an exception is allowed for nuns who are ill); Mahïśāsakavinaya (T.1421: 94c7-13); Mahāsāmghikavinaya (T.1425: p. 538a11-b1 - this vinaya associates such behaviour with the behaviour of lay people, an attitude that betrays desire); Dharmaguptakavinaya (T.1428: 770c12-771a22); Sarvāstvādavinaya (T.1435: 339a23 - b6 - this vinaya refers only to nuns who use umbrellas); Mūlasarvāstivādavinaya (T.1443: 1013b29-c20 - this vinaya has two separate rules: one for the umbrella and one for multi-coloured shoes).

${ }^{35}$ An exception is allowed for the umbrella, too: the Buddha says they may be used inside the monastery to protect the body, clothes and bedding when there is a lot of rain. They may be made of bark, leaves and bamboo (see, for instance, Dharmaguptakavinaya, T.1428: 770c28771a2). 
ascetics behave in a better way. Hence, he prohibits the use of all kinds of footwear. ${ }^{36}$ Yet, several exceptions are allowed. First, shoes are allowed when a monk is on the road with his teacher. The Dharmaguptakavinaya (T.1428: 847c19-23) justifies this with the explanation that disciples risk losing their shoes if they are obliged to remove them every time they offer something to their teacher. This exception is therefore based on pragmatism, as are most of the others. After sunset, for instance, a monk may wear his shoes when collecting water if there is a risk of stepping on a snake (T.1428: 847c23-28). Similarly, shoes may be worn when monks have painful feet or when there is rain and mud inside the monastery. In the latter case, shoes with one sole are allowed (T.1428: 848a25-28).

Clearly, shoes are permitted inside the monastery for a variety of practical reasons, except, as we saw above, when attending a ceremony, greeting a senior, or walking in the vicinity of a stüpa. This flexibility does not extend to wooden clogs though: they must almost never be worn because they make a lot of noise and disturb monks who are in contemplation (T.1428: $847 \mathrm{~b} 17-19){ }^{37}$ The Mahīśäsakavinaya (T.1421: 146c3-8) also forbids them because of their distracting noise, but then offers a second reason for the prohibition: a monk once wore wooden shoes at night, stepped on a snake and killed it. There is just one exception to the ban on wooden shoes: they may be worn in toilet facilities and washing places. ${ }^{38}$

\subsection{Taking Care of Shoes}

Even though shoes are seen as practical solutions to unavoidable problems, such as thorns and dirt, they still number among a monk's (very few) belongings, so they must be looked after conscientiously. For instance, when dogs carried away the shoes of a group of sleeping monks, the Buddha said that the shoes should have been covered with grass or placed under the monks' sleeping mats (with their undersides together) in order to protect them (Dharmaguptakavinaya, T.1428: 846a28-b2). Shoes should also be wiped clean regularly, to avoid soiling the feet or sitting and sleeping material (T.1428: 849b4-9). Any cloths used to wipe the shoes should then be washed

\footnotetext{
${ }^{36}$ For a similar story, see Pāli vinaya (Vin, vol. 1, p. 187), and Sarvāstvādavinaya (T.1435: $183 \mathrm{~b} 13-23)$.

${ }^{37}$ The Mahāsāmghikavinaya (T.1425: 513b8-16) mentions another intrusive sound: monks should not slap their shoes in front of the door of the meditation hall and then hang their footwear as "dried fish". Instead, they should put them away, with the two undersides facing each other, and cover them with a cloth. If possible, they should be placed under the monk's mat. The Sarvāstivādavinaya (T.1435: 278c20-25) also warns monks not to slap their shoes anywhere. It offers the example of monks who slap their shoes while on the road, and so startle heavenly beings. Such behaviour is deemed inappropriate.

${ }^{38}$ Mahīśāsakavinaya (T.1421: 146c7-8); Mahāsāṃghikavinaya (T.1425: $482 \mathrm{~b} 10$ - allows clogs at the place where the feet are washed); Dharmaguptakavinaya (T.1428: 847b19-21); Sarvāstvādavinaya (T.1435: 183c29-184a3 - allows special shoes when the feet are washed); Mūlasarvāstvādavinaya (T.1447: 1055b27-c2). The Pāli vinaya (Vin, vol. 1, p. 190) specifies that, with the exception of the footwear that may be worn in these particular places, shoes that cannot be put away or folded are prohibited.
} 
and dried in the sun. ${ }^{39}$ A monk should also avoid making his shoes moist, as may happen, for instance, if he washes his feet and neglects to dry them properly before stepping back into his shoes.

These rules also apply to guest monks who visit a monastery (T.1428: 930c7931a15): they should remove their shoes and carry them in one hand, as well as shake them to remove dirt. When some monks cleaned their shoes with a tree (presumably by slapping them against the trunk), the ghost of the tree was upset. Thereupon, the Buddha declared that shoes should be cleaned with stone, wood or bamboo, or by slapping the two shoes against each other. Upon entering the monastery, a monk should wash his feet with water - first the left, then the right - and ensure that both feet are dry before putting on his shoes again. ${ }^{40}$

A monk is also responsible for looking after his teacher's shoes when he leaves the monastery (Dharmaguptakavinaya, T.1428: 801c22-802a6). This implies that if the teacher enters a village and leaves his shoes in a safe place (such as a house or a shop), the disciple should, if asked, guard them and wait for the teacher to return. A monk should also help his teacher when the latter returns to the monastery (T.1428: 802a19-23): he should shake the teacher's shoes and put them in a dry area (so they do not get moist) on the left side. (The right side is associated with respect, so shoes have no place there.) Finally, the monk should wash his teacher's feet. ${ }^{41}$

\subsection{Concluding Remarks}

Shoes and practices related to shoes are connected to a wide range of positive concepts, including humility, cleanliness and respect, as opposed to negative concepts, such as luxury, dirt and disrespect. The monastic community is expected to be a model of decorum and high moral values, a paragon of cleanliness and dignity. In this context it is not surprising that shoes pose a major problem.

As potentially luxury artefacts, shoes are opposed to the image of a simple life that is cherished by the Buddhist community; and, as they symbolise frivolity, they threaten the ideal of a non-sexual life (which is especially important for women). On the other hand, shoes inevitably get dirty, so they have the potential to endanger the

\footnotetext{
${ }^{39}$ The Mahāsāmghikavinaya (T.1425: 508a5-6) specifies that a wet cloth may be used to wipe the shoes.

${ }^{40}$ Shoes may be wrapped in a piece of cloth or put in a special bag (Dharmaguptakavinaya, T.1428: $624 \mathrm{c} 18-20)$. Similarly, tools and materials for shoe repair may be stored in such a bag which may be fashioned out of bamboo, bark, wool or any type of cotton, but not leather (T.1428: 846a22-26, 849a3-4). The Mahiśásakavinaya (T.1421: 147a1-5) does allow the use of leather, but warns that such a bag should never be washed since it will rot. Instead, the dust should be wiped out. The bag should not be used any more if it gets too dirty.

${ }^{41}$ See also T.1428: 904c13-17, 933b17-21, 934b26-c1. Similar signs of respect should be shown to teachers who are ill or old (T.1428: 802c26-803a1).
} 
community's spotless image. ${ }^{42}$ They strongly diminish the dignity of the samgha and the dharma, undermining both their social position and their value to the lay world. Inside the monastic order, shoes disturb the deferential relations between seniors and juniors; and when monks and nuns wear shoes during ceremonies or in the vicinity of a stüpa, they disregard the Buddha, the dharma and the samgha. Wearing shoes is thus easily connected to the low moral values of monks and nuns who behave improperly, and it can imply that such people are not totally committed to a monastic life.

In sum, shoes are no more than practical items of clothing, and they should be avoided as much as possible. They have many undesirable aspects, yet they are often necessary to shield the body and robes from dirt or to protect the feet from injury. They also allow monastics to travel over long distances. So, footwear, irrespective of its negative connotations, is sometimes unavoidable. In such circumstances, the shoes must be very modest, and they should be removed in any situation that calls for respect to be paid.

China's vinaya masters pored through these guidelines when they started to study the Indian disciplinary texts. Given the significance of shoes in daily life, it is unsurprising that some of these masters felt the need to amend or supplement the traditional regulations in order to promote a proper Buddhist attitude towards footwear, clothes and the body in a Chinese context.

\section{Shoes in Chinese Buddhist Communities}

\subsection{Shoes in the Lay Community}

Chinese Buddhist monastics may have given little thought to the appearance of footwear in India when they first read the vinaya guidelines. In fact, as Chinese shoes were generally very similar in design, the guidelines probably seemed relatively straightforward. In mediaeval China, leather, straw and silk shoes were very common, as they were in India. ${ }^{43}$ Any form of decoration was seen as a sign of luxury. Raised shoes were popular with China's upper classes from the Sui dynasty (589-618) onwards, with the tips of such shoes turned upwards and extensively decorated, often with embroidered silk. ${ }^{44}$ A mural painting in the Yulin cave 25 (close to Dunhuang) features an interesting example of 8th-century elite footwear (Duan 1993, p. 11). First, it shows a lady wearing shoes with raised tips as her hair is shaved prior to en-

${ }^{42}$ As Steven Collins (1997, pp. 194-199) has clearly shown, a monk or nun must display "a spotless performance" to maintain social position, even though many texts also emphasise the impermanence and impurity of the body.

${ }^{43}$ For a historical overview on Chinese footwear, see, in particular, Luo (1990; updated 2007, richly illustrated). Also beautifully illustrated is Luo (2014). For short overviews in English, see DeMello (2009, pp. 54-57) and Zamperini (2006, pp. 200-203).

${ }^{44}$ See Luo (1990, pp. 117-118) for detailed drawings. Shoes with raised tips, made out of satin and flax, have been found in tombs in the Turfan area (see Luo, 2007, pp. 118 and 123). For a description of very similar shoes in 8th-century Japan, which was heavily influenced by Chinese footwear culture, see Tanaka (2015). 
tering a monastic community. In the next image, the same woman bows to the Buddha while kneeling on a mat. She is now wearing full monastic clothing, yet the shoes with raised tips still feature prominently, perhaps signifying that the woman was allowed to keep her lay shoes after joining the monastery. They are decorated at the tips and are quite beautiful. Interestingly, though, she has removed them before bowing to the Buddha, in all likelihood as a sign of respect. As we will discuss later, she has also covered her feet with her robes, in accordance with Chinese customs and as demanded in the disciplinary texts. When footwear features in the other murals in the cave, the shoes tend to be modest, often with only slightly raised tips.

Lay people commonly wore boots and wooden clogs, both of which are mentioned in the vinaya texts. According to Luo (1990, pp. 38-40; 2007, pp. 15-17), wooden clogs were initially worn mostly in the south of China and in the mountainous regions of the north. ${ }^{45}$ In the latter region they featured wooden spikes, which were removable, at least from the Tang dynasty (618-907) onwards. Cloth shoes, often with multiple cloth soles, were apparently popular in mediaeval China, but these are not specifically mentioned in any of the vinayas. DeMello (2009, p. 55) briefly explains how the soles were made: they were first stitched together, then soaked in water, hammered and dried. According to Luo (1990, pp. 46-47; 2007, pp. 25-27), cloth soles were used in China well before the Qin dynasty $(221-206 \mathrm{BC}){ }^{46}$

In addition to being familiar with the types of shoes mentioned in the vinayas, many Chinese readers surely had an implicit understanding of at least one of the customs outlined in the texts, because, as in India, they were used to removing their shoes in certain ceremonial situations (see Luo 1990, pp. 92-94; 2007, pp. 73-76). Specifically, in mediaeval China - as demonstrated by Luo (2014, pp. 92-95) on the basis of several ancient drawings - one tended to remove one's shoes, albeit usually without exposing one's feet, when taking a seat and receiving guests inside a (probably upper-class) house. Luo argues that there were practical reasons for this tradition, such as to keep the feet cool indoors.

Below, I focus on what Chinese Buddhist masters thought about shoes and how they should be worn. I begin with the major vinaya masters and conclude with the rules that were drafted for the large public monasteries of the Song dynasty (9601279) and became the model for centuries thereafter.

\subsection{Early Chinese Commentaries}

\section{Da biqiu sanqian weiyi 大比丘三千威儀}

One early commentary that offers a glimpse of how rules on daily practices were interpreted in mediaeval China is the Da biqiu sanqian weiyi 大比丘三千威儀

\footnotetext{
${ }^{45}$ On mountain shoes, see also Luo (2014, pp. 48-54).

${ }^{46}$ Luo $(2014$, p. 32) dates the first Chinese cloth shoes to the Spring and Autumn Period (8th-5th century BC).
} 
(Great (Sūtra) of three thousand dignified observances of a monk, T.1470) which was probably compiled in the 5 th century. ${ }^{47}$ This commentary clearly views shoes as dirty and stipulates that soiled shoes must be removed when entering a room at dusk (T.1470: 915c8). One should also be aware of dirt at mealtimes: if one needs to spit, one should step on the saliva with the sole of a shoe; and carrying shoes leads to soiled hands, so once the hands have been washed, one should not touch one's shoes again (T.1470: 921a29-b2) ${ }^{48}$ Regulations relating to behaviour in and around a stüpa also leave readers in no doubt that shoes are inherently dirty, and could therefore be associated with a lack of respect. Still, these stipulations are not as strict as those that appear in the vinaya texts. In addition, they are not wholly consistent. One rule, for instance, says that shoes should be placed at the foot of the stūpa before entering to honour the Buddha when it is raining (T.1470: 915c3). This suggests that shoes may be worn inside the stüpa on dry days. Another rule (T.1470: 916a5) stipulates that one should not take shoes used in the monastery's backyard (she hou 舍後) to a stūpa, while a third (T.1470: 923b22) specifies that shoes should not be worn when sweeping a stüpa. Also, when the Da biqiu sanqian weiyi discusses which footwear may be worn at the poșadha ceremony, although it stipulates that both white shoes (commonly associated with lay people) and clogs are prohibited, it has nothing to say about shoes of any other colour (T.1470: 925b11-12). Hence, it is somewhat less rigid than the Indian vinaya texts.

\section{Sifen lï shanfan buque xingshi chao 四分律刪繁補關行事鈔}

Perhaps the most prominent vinaya master of mediaeval China was the 7th-century monk Daoxuan (道 宣, 596-667). Already very influential during his lifetime, his writings are now considered to be standard interpretations in Chinese Buddhism, and he is seen as the founder of the Nanshan lüzong 南山律宗 ('vinaya school of Nanshan') which promoted vinaya rules and especially those found in the Dharmaguptakavinaya. One of Daoxuan's most famous commentaries is the Sifen lü shanfan

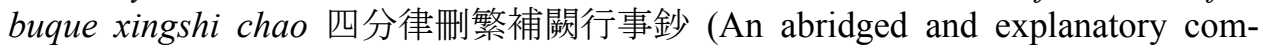
mentary on the Dharmaguptakavinaya, T.1804) in which he discusses the rules for monks and nuns. As the title suggests, this is primarily an analysis of the Dharmaguptakavinaya, but it also contains references to and interpretations of many other vinaya texts.

As we will see, Daoxuan was interested in the rules relating to footwear, although he paid more attention to other items of clothing, such as robes. Where shoes

${ }^{47}$ Although the colophon to the text presents it as a Han translation by An Shigao (安世高, 2nd century), the Da biqiu sanqian weiyi was probably compiled in China during the 5th century. See Hirakawa (1970, pp. 193-196).

${ }^{48}$ Another footwear-related rule is concerned with safety rather than cleanliness: when stepping out of bed, one should shake one's shoes (presumably to ensure that no small creatures are lurking inside) (T.1470: 915a25). On more stipulations relating to the dormitory in mediaeval China, see Heirman (2012, pp. 435-442). 
are concerned, he generally stays very close to the vinaya texts: for instance, he stresses that luxury shoes are unacceptable, that only "bad colours" may be used and that wooden clogs are allowed only in toilet facilities and when one washes one's feet (T.1804: 110b27-c4). Similarly, he points out that shoes with multiple soles may be worn in border regions, where the roads tend to be difficult, while boots are acceptable in cold regions (T.1804: 110a28-b1; 110b16-19). And he stresses that shoes should be removed as a sign of respect when greeting a superior, attending a ceremony, or visiting a stüpa (T.1804: 20a4-5; 35a26-28; 90c17-18). He justifies this regulation with reference to the Pinimu jing 毘尼母經 (Vinayamātrkā?, T.1463), ${ }^{49}$ stating that lay people will criticise a monk's rudeness if he wears shoes when honouring the Buddha (T.1804: 110b19-20), or will themselves become rude (T.1804: 132b2022). ${ }^{50}$ In addition, in three passages that reveal the importance of the vinaya rules to Daoxuan, he refers to the Mahisíāsakavinaya's stipulation (T.1421: 147a16-18) that a monk may accept new shoes only after a lay attendant (jing ren 淨人, kalpikāra) has "purified" them by walking several steps in them first (T.1804: 86c3-4; 110b21-22; $111 \mathrm{c} 2){ }^{51}$

In sum, Daoxuan certainly holds the vinaya texts in high regard when discussing footwear. He refers to the rules that need to be applied, and to the situations when shoes should be removed. Still, these situations present the eminent vinaya master with some problems. For instance, must one always remove one's shoes when greeting a superior? And is it really necessary to enter a village barefoot, as the vinaya texts stipulate? In fact, Daoxuan demurs on both of these issues.

He expresses doubts about the appropriateness of removing one's shoes when greeting a superior (T.1804: 110b20-21) by referring to the Fo shuo Mulian wen jie lü zhong wu bai qing zhong shi 佛說目連問戒律中五百輕重事 (On the five hundred questions asked by Maudgalyāyana on light and heavy things, as told by the Buddha, T.1483). ${ }^{52}$ In this compilation of questions and answers relating to vinaya matters, the conclusion is that shoes or boots may be worn when paying homage as long as the footwear is “pure” (jing jie 淨潔) (T.1483: 979c15). At first, the meaning of "pure" seems unclear: it might mean "clean", "allowable according to the rules", or both. However, Daoxuan seems to think that it refers primarily to the rules, since his

${ }^{49}$ An unknown school's commentary on the prätimokșasūtra, translated at the end of the 4 th or beginning of the 5 th century. On the title, see Clarke (2004, p. 87).

${ }^{50}$ The latter formulation is closer to the original source, the Pinimu jing, which says that shoes may not be worn when entering or circumambulating a stüpa (although boots may be worn when entering, presumably in cold regions). This prohibition was intended to stop common people developing an arrogant and rude attitude (T.1463: 825c4-7).

${ }^{51}$ In T.1804: 86c3-4, Daoxuan suggests five to six steps, in accordance with the Mahāsāmghikavinaya (T.1425: 482a22-24). In T.1804: 110b21-22, he suggests seven steps, in accordance with the Mahīśāsakavinaya.

${ }^{52}$ The translator of this text is not known. Its colophon in the Taishō edition says that it is recorded in the Dong Jin lu 東晋錄 (Catalogue of the Eastern Jin Dynasty) (265-420) which refers to master Dao'an's (道安) catalogue, the Zongli zhongjing mulu 綜理眾經目錄, completed in AD 374 (see T.2145: 33a14). 
next line discusses the aforementioned stipulation in the Mahissáăsakavinaya: a monk may wear new shoes as long as a jing ren 淨人 has walked a few steps in them first. This latter regulation is clearly concerned with adhering to the rules, rather than cleanliness. Thus, by using Maudgalyāyana's questions as supporting evidence, Daoxuan permits monks to wear their shoes (as long as these are made in accordance with the rules) when greeting a superior - a practice that was probably very common in China.

Daoxuan also seems to advocate a flexible interpretation of the vinaya rules when discussing the stipulation that one should enter a village barefoot. His reasoning clearly suggests that Chinese monks usually did not remove their shoes in such circumstances and, possibly, that they were not even expected to do so. Moreover, he suggests that, far from being a breach of the vinaya rules, the guidelines - and specifically the Dharmaguptakavinaya - permit such behaviour (at least on careful reading). His argument goes as follows (T.1804: 110b26-27):

\section{文中因在道在聚落。脫革㞞偏祖有廢。佛言。 若有所取與隨時 (準此開入聚落中不脫革㞞偏祖。明文證之)。}

In the text [the Dharmaguptakavinaya] one can note that when on the road or in a village, there is some kind of leniency when one removes one's shoes or uncovers one's shoulder. The Buddha says that when there is an act of accepting and giving, one should act according to the circumstances (this shows that one can enter a village without removing one's shoes or uncovering one's shoulder. If one clearly understands the text, this is proven). ${ }^{53}$

Here, Daoxuan is probably referring to a passage which suggests that one should act pragmatically when in the house of a lay person, or on the road at sunset, or when something must be passed to or received from a superior, according to the circumstances. Therefore, one does not have to remove one's shoes every time one enters a village (T.1428: 847c14-28). Daoxuan extends this rationale, though, and concludes that one is never obliged to be barefoot when entering a village. Another vinaya master Yuanzhao 元照 (1048-1116), who commented extensively on Daoxuan's works, noted: "In the west, it was seen as inappropriate to wear shoes when among lay people. But, in this land, it is the opposite ... The master [Daoxuan] wanted to have the monks wear shoes according to [the habits] of the region. He therefore refers to this passage" (T.1805: 369c12-16). ${ }^{54}$

${ }^{53}$ This seems to relate to a more general principle, also discussed at a later date by the monk Yijing 義淨 (see below): in some situations, one may make a decision according to the circumstances, as long as one continues to respect the spirit of the vinaya rules. For details, see, among others, Heirman (2008).

${ }^{54}$ Many thanks to Fa Ling (Ghent University) for pointing out this passage. See also note 15, above. 


\section{Shimen guijing yi 釋門歸敬儀}

In a study of regional customs, Yifa (2002, p. 273, note 53) refers to another text compiled by Daoxuan - the Shimen guijing yi 釋門歸敬儀 (Buddhist rites on obeisance and veneration, T.1896) - in which the vinaya master makes a most interesting remark (T.1896: 862a24-27):

The way to show respect to someone is different in India and in China. In India, one does not salute so often, but one honours someone by circumambulation. Here in China, one does not circumambulate, but one salutes often. In India, one shows one's bare shoulder and feet when paying respect to someone. Here in China, one covers oneself and one wears sandals ( $j u$ 猸) when paying respect.

Here, it is clear that Daoxuan advocates the standard Chinese procedure to pay respect, rather than the Indian guidelines. A little later in the Shimen guijing yi, he again highlights the importance of respect when discussing some variations that have arisen as pragmatic responses to climatic conditions (T.1896: 863a16-20):

In China, when people meet their superiors, it is always in a hall. Therefore, one does not take off one's shoes. There was a time when people who entered a hall took off their sword and their shoes. But that is an old custom. Central India is both humid and hot. One makes shoes out of leather and one is allowed to wear them. When meeting a superior, one takes off one's shoes. In cold regions, one wears shoes, as this is appropriate. $^{55}$

In the same passage, Daoxuan also discusses the use of leather. In his commentaries on the vinayas, he consistently adopts the standard vinaya term for monastic footwear - gexi 革㞞 - in which ' $g$ e' refers to leather. He also uses the term pi 皮 ('skin, hide'; see, for instance, T.1804: 110b27-28) when referring to material that is used to make shoes. Therefore, here at least, he takes the vinayas' line by advocating the use of leather with certain restrictions. In his manuals, however, he uses other terms for footwear - including $j u$ 㞛 ('sandal') and xie lï 鞋履 ('shoe'; see, for instance, T.1897: 869c14) - words that have no connection with leather. These differences may be explained by the fact that Daoxuan's manuals mainly aim to prescribe Chinese normative standards. In them, he acknowledges that China and India are very different places, so leather should not be used when making shoes for Chinese monastics. ${ }^{56}$

\footnotetext{
${ }^{55}$ Nevertheless, one may remove one's shoes when paying homage if one uses a mat (T.1896: $863 \mathrm{a} 20-21$ ), as we saw when discussing the mural in Yulin cave 25.

${ }^{56}$ The use of leather in Chinese monastic environments needs to be explored further. This issue is reminiscent of the controversy surrounding the use of silk in monasteries. While silk was a common material in mediaeval China, its production involved the killing of silk worms. Daoxuan therefore strongly opposes its use. For a discussion, see, in particular, Kieschnick (2003, pp. 98 99) and Young (2013, pp. 38-43; 2015, pp. 186-216). See also note 26, above.
} 


\section{Jiaojie xinxue biqiu xinghu lüyi 教誡新學比丘行護律儀}

The last of Daoxuan's influential manuals is the Jiaojie xinxue biqiu xinghu lüyi 教誡 新學比丘行護律儀 (Exhortation on manners and etiquette for new monks in training, T.1897). ${ }^{57}$ This text provides extensive guidelines for novice monks on a variety of daily matters with the aim of integrating the newcomers into the (ideal) monastic life. Once again, Daoxuan focuses on the themes of cleanliness and respect. Inevitably, then - because they come into contact with dirt and can generate disturbing noise - the manual includes several regulations about the proper use of shoes. For instance, when walking, the heels should always touch the ground first in order to keep the noise of one's footsteps to a minimum and display respect for one's fellow monks (T.1897: 870a23-24). Moreover, disciples should pay particular respect to their teachers by looking after their shoes, as these can be rather dirty objects (T.1897: 869c14).

Daoxuan also offers some practical advice on shoes that are worn within the confines of the monastery. It is clear that he views shoes in general as unclean, and he has a particular aversion to wooden clogs ( $m u$ tu 木揬 $),{ }^{58}$ which should not be worn in the vicinity of places that are to be honoured (T.1897: 870a21-22). All types of shoes have the potential to spoil clean environments, or demean a monk's reputation when used improperly. At night, for instance, when shoes are hung up in the sleeping room, they should not hang directly above a monk's head, pointing at his face (T.1897: 871a28-29). From this, it seems that shoes have the capacity to "soil" a person, at least symbolically.

In the refectory, shoes should be removed and then squeezed between the fingers (T.1897: 871c9-10). Moreover, the removal must be done properly: shoes should not be kicked off or grasped. Instead, they should be held carefully between the fingers and put to one side. Paradoxically, given his meticulous guidelines on other aspects of proper behaviour, Daoxuan offers no guidance on how monks should sit once they have removed their shoes: cross-legged or with their feet on the ground. In his Sifen lü shanfan buque xingshi chao, for instance, he simply stipulates that monks should sit (ju zuo 踞坐) when eating, just as the Buddha did (T.1804: 137a46). ${ }^{59}$ The basic meaning of $j u$ zuo is 'to squat on one's heels', but it is difficult to imagine monks squatting in a refectory, as these rooms always had a bench.

In the same text, Daoxuan explains that there are two ways of sitting (T.1804: 142c13-14):

坐法有二。一結加跌。二踞坐。

There are two ways of sitting: one is cross-legged; two is ju zuo.

\footnotetext{
${ }^{57}$ On this text, see Yifa (2002, pp. 26-28).

${ }^{58}$ The word $t u$ 揬 is very occasionally used for footwear. In this context, it clearly refers to (wooden) clogs.

${ }^{59}$ Here, Daoxuan is referring to the Da biqiu sanqian weiyi (T.1470: 914a24-27).
} 
This short passage indicates that $j u$ zuo cannot be interpreted as 'cross-legged'. In his commentary on Daoxuan's text, the vinaya master Yuanzhao (1048-1116) adds (T.1805: 320b20-21):

\section{踞坐謂兩足路地。}

Ju zuo means that both feet touch the ground.

Although this does not eliminate the possibility that monks ate while squatting, a more feasible interpretation is that they sat on a chair or a bench with their feet touching the ground during mealtimes. From that, one might conclude that this was Daoxuan's favoured sitting position. However, his Jiaojie xinxue biqiu xinghu lüyi implies a different posture when attending a meal in the refectory, because it states that neither the feet nor the ankles should be exposed under the table (T.1897: 872b8-9). This suggests a cross-legged position, especially when one remembers Daoxuan's insistence on the removal of shoes in the refectory. On the other hand, he might have been advocating covering the bare feet and ankles with monastic robes. In this way, the monks could sit on a bench with their feet on the floor while ensuring that they did not expose their feet and ankles, which would be seen as improper behaviour, an issue to which we will return below.

Finally, toilet facilities are considered particularly dirty, so any shoes that are worn within them should never be worn elsewhere in the monastery. Instead, when a monk arrives at the toilet facilities, he should exchange his regular shoes for privy shoes, ${ }^{60}$ always ensuring that the two types of shoes never touch each other. Therefore, privy shoes must never be stored in a place where monks often walk by with clean shoes (presumably to ensure that the monks do not trip over them). Finally, if a monk notices that the toilet shoes are dirty, he should clean them (T.1897: 873a9-10, $14-15){ }^{61}$

\subsection{Chinese Travellers' Accounts}

Unsurprisingly, the accounts of Chinese monks who travelled to India in search of ideas or new texts contain a great deal of information on daily practices. The most prolific of these authors was Yijing 義淨, who lived in India and South Asia between 671 and 695. He discusses his travel experiences - with frequent reference to the vinaya texts - in the Nanhai jigui neifa zhuan 南海寄歸內法傳 (Account of Buddhism sent from the south seas, T.2125). ${ }^{62}$ Given his reliance on the vinayas, it is not always

${ }^{60}$ The Mülasarvāstivādavinaya (T.1451: 247a23-24) is explicit on this issue: privy shoes, which are made out of wood ( $m u$ l $\ddot{u}$ 木履), should be available outside the toilet facilities and should be put on when entering.

${ }^{61}$ The term used for 'toilet shoes' is chu lü 觸履 (lit. 'shoes that touch [presumably dirt]'). Given that in his aforementioned vinaya commentary (Sifen lü shanfan buque xingshi chao, T.1804: 110c3-4) Daoxuan advocates the use of special, wooden shoes at toilet facilities, it is fair to assume that "shoes that touch [dirt]" refers to shoes used at the toilet.

${ }^{62}$ For an English translation, see Li (2000). 
clear whether Yijing is discussing situations he has observed or texts he has read. In that sense, his (and all of the other) travel reports must be approached critically and contextualised. Nevertheless, his account indisputably provides invaluable information on how this influential monk envisaged the (ideal) monastic life.

In his travel account (T.2125: 206c12-21) Yijing reminds his readers that monks should be barefoot in the presence of a statue that is to be venerated or when approaching a teacher. In all other circumstances he advocates flexibility and states that shoes may be worn. It is also acceptable to adapt footwear to regional conditions; so, for instance, short boots are allowed in cold regions. ${ }^{63}$ Clearly, then, Yijing is most concerned with issues of respect and propriety. ${ }^{64}$ Hence, he stresses - just as the vinayas do - that shoes or boots should be removed before circumambulating a stūpa of the Buddha or entering a hall. He also complains that many monks violate these rules (a recurring theme in much of his writing).

Yijing is also concerned with the proper sitting position of monks when eating. He states that each monk should sit on a small chair, with his feet on the ground, as Yijing witnessed in India and as the Buddha stipulated (T.2125: 206c22-207a16). He supports his argument by saying that the texts insist that the feet must be washed after eating, so they must have touched the ground during the meal itself. (Extending this rationale, it seems reasonable to conclude that the monks were supposed to eat barefoot, although Yijing himself never mentions this.) Yijing further explains that monks sat in the correct position during mealtimes when Buddhism was introduced to China. (In this passage he uses the term ju zuo 踞坐 which in this context probably means 'with one's feet on the ground'.) But then, at some point in the Jin dynasty (265-420), an error occurred and Chinese monks started to sit cross-legged (jia zuo 跏坐) on long benches. Still, Yijing acknowledges that he will never be able to convince his fellow monks to sit in the traditional way. In one of his translations (T.1453: 498c21-22) he is even reluctant to condemn the more recent practice, admitting "it is hard to say [what one should do]" ${ }^{65}$ In any case, Yijing seems certain that Chinese monks sat cross-legged during mealtimes, and, as indicated by Daoxuan, removed their shoes before doing so.

\subsection{Qing gui 清規, 'Rules of Purity'}

From the 8th century onwards, a new genre of rules started to appear - the so-called "rules of purity" (qing gui 清規) which would prove to be particularly popular among

${ }^{63}$ Also permitted in the travel report of the monk Xuanzang 玄奘 who travelled in India and some parts of Central Asia between 627 and 644. He refers to a particularly cold place in western India where the Buddha allowed the wearing of boots (xue 靴) (T.2087: 938b19-20).

${ }^{64}$ Later in his travel account (T.2125: 216a6-8) Yijing briefly mentions that boots and shoes with ornaments should not be worn.

${ }^{65}$ For a detailed discussion, see Heirman (2008, pp. 268-269). 
Chan monks. Although they continued to rely on earlier vinaya texts, ${ }^{66}$ the compilers of these rules focused on the practical organisation of large public monasteries. ${ }^{67}$ The oldest extant code is the Chanyuan qing gui 禪苑清規 (The pure rules for the Chan Monastery, W 111: 875-942), compiled by Changlu Zongze 長蘆宗臤 (?-1107?) in $1103 .^{68}$ These rules have been updated regularly and have become the standard code for the organisation of all Chinese public monasteries, regardless of school affiliation. They did not replace the earlier vinaya rules but rather supplemented them by offering pragmatic organisational guidelines. The most influential revision of the Chanyuan qing gui is the Chixiu Baizhang qing gui 敕修百丈清規 (Baizhang's rules of purity revised on imperial order, T.2025), compiled by Dongyang Dehui 東陽德 輝 between 1335 and 1343. ${ }^{69}$ Again, all of these texts outline the ideal organisation of a Buddhist monastery, as envisaged by their authors/compilers. Moreover, the practices they outline must have had at least some significance for their readers. Below, I focus on how these manuals view the use of footwear as part of the normative ideal that they try to establish for China's large monasteries.

As we have seen, footwear was linked to respect and cleanliness in the vinaya texts and the early Chinese commentaries, but both of these concepts are much more prevalent in the "rules of purity". For instance, exposure of the body is often discussed in relation to respect, so the Chanyuan qing gui stresses that monks should attempt to keep themselves covered, especially during ceremonies. This emphasis on not revealing the body probably prompted Chinese monks to start wearing socks beneath their shoes. See, for instance, the following passage, which urges monks to behave properly when attending a morning sermon or an evening instruction (W 111: $886 \mathrm{~b} 11-12)$ :

\section{偏衫下須著內衣不宜露體。鈐口履鞋禮須穿襪。}

Under his short garment he [a monk] should wear an undergarment so as not to expose the body. His "bell-mouth" shoes should be worn correctly with socks. ${ }^{70}$

In addition, as discussed above, removing one's shoes when meeting someone was not a sign of respect - rather the contrary - even in Daoxuan's time. Nevertheless,

\footnotetext{
${ }^{66}$ Yifa (2002, pp. 3-98) has analysed this reliance on the vinayas and other early disciplinary texts in detail.

${ }^{67}$ In public monasteries the abbacy is not passed down through a tonsure family. See, among others, Schlütter (2005).

${ }^{68}$ Translated into English by Yifa (2002).

${ }^{69}$ For more on these later texts, see, among others, Fritz (1994, pp. 16-27) and Yifa (2002, pp. 47-50). For a translation of the Chixiu Baizhang qing gui into English, see Ichimura (2006).

${ }^{70}$ Based on Yifa (2002, p. 139). In addition to the standard terms for shoes, the Chanyuan qing gui contains the more specific term ling kou (lï) xie 鈴口(履)鞋 (lit. 'bell-mouth' shoes). See, for instance, W 111: 886b12. Yifa (2002, p. 251, note 41) suggests that this term may refer to the shape of the shoe, and points out that they were later called "nose-high" (bi gao 鼻高) shoes. To me, this seems to indicate shoes with raised tips which were very common in China at the time. Guo (2001, pp. 121-124) has shown that monastics wore these shoes, although they were less decorated than lay people's shoes.
} 
shoes can get filthy, so they should be removed during mealtimes. A desire to avoid dirt is probably also the reason why the Chanyuan qing gui recommends changing shoes prior to entering a monastery after travelling outside (W 111: 878b1-2). Such journeys should be made in straw sandals (cao xie 草鞋) without socks. After washing the feet, these sandals should be exchanged for shoes and socks which are then worn within the precincts of the monastery. At mealtimes these shoes are removed before the monk sits cross-legged on a platform to eat. Still, he should ensure that his robes cover his feet (W 111: 881a3-4).

Regulations for attending a tea ceremony are similarly detailed, again to avoid exposing the body (W 111: 883a11-12). In this instance, rather than sitting on a platform (chuang 床), the monk would sit on a chair (yizi 椅子) - possibly cross-legged, although this is not specified. The regulations also insist that shoes must be removed and carefully set to one side. No explanation is given for why this is necessary; perhaps the compilers simply thought that it was impractical to sit cross-legged while wearing shoes. Moreover, shoes can soil one's clothes, which is why the Chanyuan qing gui insists on their removal before entering a toilet (W 111: 912a9). Once removed, they should be arranged neatly. The text does not mention special toilet shoes.

The Chixiu Baizhang qing gui confirms all of these guidelines and then provides some additional details. When arriving at a monastery, a monk should wash his feet and then change into shoes and socks that may be worn inside (T.2025: 1140a11). He should never enter a Buddha hall or a dharma hall in his travelling shoes. He should also not wear "monastic shoes" (seng xie 僧鞋; presumably the shoes that are worn inside the monastery) with bare feet (T.2025: 1145c15-16). In the refectory, he should sit with his feet on a wooden bench (so, presumably, crossed-legged) after putting his shoes under the bench using his feet. Once seated, he should be careful not to reveal his knees or underwear (T.2025: 1144a7-10). Shoes should be exchanged at toilet facilities: neither monastery shoes nor toilet shoes should be left in disarray (T.2025: 1145b20, b23). A monk should not enter the bathhouse with bare feet, but instead wear special sandals (T.2025: 1131b20; 1146a15-16). These sandals are probably kept on throughout the bathing process, since feet may not be dipped in the water (T.2025: 1146a21). Finally, shoes may be dried at a fireplace, as long as care is taken not to scorch them (T.2025: 1146b2).

\section{Conclusion}

Footwear is an important part of monastic attire: shoes separate the body from the ground, so they inevitably touch dirt. At the same time, they protect the body from both dirt and injury. Moreover, the wearing of shoes, or their removal, can signify either respect or disrespect, depending on context. For instance, the vinayas generally advocate the removal of one's shoes as a sign of respect, whereas doing so could be considered disrespectful in mediaeval China.

The multifaceted relationships between footwear and the human body, other items of clothing, and monastic and lay environments compelled generations of vinaya 
masters to compile a series of normative guidelines on the correct use of shoes. Of primary importance, in both India and China, is the stipulation that shoes have to be modest in terms of shape and material used. They are worn only because they are necessary to protect the feet, so they should not display any hint of luxury or frivolity, both of which run counter to the monastic ideal of living a simple life. In other respects, however, the two traditions - in India and China - start to diverge. In India the inclination is to keep shoe-wearing to a minimum, whereas in China there is a general aversion to going barefoot. This is closely linked to the two regions' contrasting views on exposing the body (and particularly, in this context, the feet).

As has been mentioned throughout this paper, shoes are inevitably connected to dirt because they form a barrier between the wearer and the muddy, thorny or dusty ground. Therefore, they are often connected to the notion of disrespect, both inside the monastic community and when meeting lay people. Hence, the compilers of the vinayas urge monks and nuns to remove their shoes during ceremonies and when they are in the vicinity of a stüpa - out of respect for the Buddha, the dharma and the samgha. In China, however, the rules are less straightforward. On the one hand, Chinese monastics acknowledge that shoes are connected to dirt, so they understand why they should be removed in certain circumstances. On the other hand, in China, showing one's naked feet to a fellow monastic, or indeed a lay follower, could also be seen as a sign of disrespect. This paradox probably explains why Chinese masters felt the need to offer detailed advice on the use of various types of footwear in specific situations, and to formulate extra guidelines on the general use of shoes and socks. So, for instance, any monk who arrives at a Chinese public monastery exchanges his straw sandals for a cleaner pair of shoes. Moreover, once inside the confines of the monastery, he exchanges these monastic shoes for different footwear whenever he goes to the toilet or bathes (echoing the vinaya guidelines on proper toilet and bathing practices). In addition to the monastic shoes, socks are compulsory in Chinese monasteries in a bid to keep the whole body covered. Similarly, on the rare occasions when shoes are removed, they should be put to one side carefully, and the feet must be covered with the monk's robes.

The formulation of rules for outside the monastery must have been much more difficult, because Chinese monks and nuns can travel with nothing but their straw sandals, so exchanging one pair of shoes for another is impossible on the road. Moreover, Daoxuan had to find a way to abide by the vinaya rules (which favour the removal of shoes in many situations) while also respecting Chinese social customs (which generally have an aversion to bare feet). He did this by scrutinising the vinaya texts in depth and arguing that they do not, in fact, demand the removal of shoes when entering a village.

In conclusion, shoes are clearly linked to the concepts of simplicity, cleanliness/dirt and respect in the Buddhist communities of both India and China. They should always be simple and, if at all possible, clean because, as many Buddhist masters emphasise, cleanliness is a strong sign of respect. In India, this prompted the compilers of the vinaya texts to urge monks and nuns to remove their (dirty) shoes in many situations out of respect for the lay community, their fellow monastics, and espe- 
cially the Buddha, the dharma and the samgha. By contrast, Chinese masters developed guidelines for a range of footwear so that some shoes can be kept relatively clean, while others are worn when travelling or visiting toilet facilities. Chinese monks also wear shoes and socks most of the time within the monastery, since naked feet (and ankles) are seen as even worse than footwear. Wearing shoes is therefore considered a sign of respect in China.

Footwear was therefore a problematic issue for the compilers of Buddhist guidelines, whether in India or China. Shoes were worn reluctantly in India, where monastics viewed them as necessary, unavoidable items of clothing that should be removed whenever possible. By contrast, wearing shoes in China came to signify respect, because even soiled footwear was considered preferable to naked feet.

\begin{abstract}
Abbreviations
T Taishō shinshū daizōkyō 大正新修大蔵經. 85 vols, ed. Takakusu Junjirō 高楠順次郎 and Watanabe Kaigyoku 渡邊海旭. Tokyo, Taishō Issaikyō Kankōkai, 1924-1934.

Vin Vinaya Pitakam: One of the Principal Buddhist Holy Scriptures in the Pāli Language. 5 vols, ed. Herman Oldenberg. 1879-1883. Reprint, London, Pali Text Society, 1969-1993.

W Wan xuzang jing 飞續藏經. 150 vols, ed. Xinwenfeng Bianshenbu 新文豐編審部. Taipei, Xinwenfeng Chuban, 1905-1912.
\end{abstract}

\title{
Bibliography
}

Ciyi 慈怡 (ed.) (1989): Foguang da cidian 佛光大辭典. Gaoxiong, Foguang Chubanshe. Reprint: Beijing, Beijing tushuguan chubanshe.

Clarke, Shayne (2004): Vinaya Mātrkā - Mother of the Monastic Codes, or just Another Set of Lists? A Response to Frauwallner's Handling of the Mahāsāmghika Vinaya. Indo-Iranian Journal Vol. 47, pp. 77-120.

Clarke, Shayne (2014): Family Matters in Indian Buddhist Monasticisms. Honolulu, University of Hawaii Press.

Collins, Steven (1997): The Body in Theravāda Buddhist Monasticism. In: Coakley, Sarah (ed.): Religion and the Body. Cambridge, Cambridge University Press, pp. 194-203.

DeMello, Margo (2009): Feet and Footwear: A Cultural Encyclopedia. Santa Barbara, Calif., Greenwood Press.

Duan Wenjie 段文傑 (ed.) (1993): Dunhuang shique yishu, Yulin ku di erwu ku fu di yiwu ku (Zhong Tang) 敦煌石窟藝術, 榆林窟第二五窟附第一五窟 (中唐) [Dunhuang cave art, Yulin cave 25, with some additions of cave 15 (Middle Tang)]. Nanjing, Jiangsu meishu chubanshe.

Frauwallner, Erich (1956): The Earliest Vinaya and the Beginnings of Buddhist Literature. Roma, Istituto Italiano per il Medio ed Estremo Oriente.

Fritz, Claudia (1994): Die Verwaltungsstruktur der Chan-Klöster in der späten Yuan-Zeit, Das 4. Buch der Chixiu Baizhang qinggui, übersetzt, annotiert und mit einer Einleitung versehen. Bern, Peter Lang.

Funayama, Tōru (2004): The Acceptance of Buddhist Precepts by the Chinese in the Fifth Century. Journal of Asian History Vol. 38, No. 2, pp. 97-120. 
Gombrich, Richard (2009): What the Buddha Thought. London, Equinox.

Guo Huizhen 郭慧珍 (2001): Hanzu fojiao sengjia fuzhuang zhi yanjiu 漢族佛教僧伽服裝之研究 [A study on monastic clothing in Chinese Buddhism]. Taipei, Fagu wenhua.

Heirman, Ann (2002): 'The Discipline in Four Parts', Rules for Nuns According to the Dharmaguptakavinaya. 3 vols. Delhi, Motilal Banarsidass.

Heirman, Ann (2007): Vinaya from India to China. In: Heirman, Ann-Bumbacher, Stephan-Peter (eds): The Spread of Buddhism. Leiden, Brill, pp. 167-202.

Heirman, Ann (2008): Indian Disciplinary Rules and Their Early Chinese Adepts: A Buddhist Reality. Journal of the American Oriental Society Vol. 128, No. 2, pp. 257-272.

Heirman, Ann (2012): Sleep well! Sleeping Practices in Buddhist Disciplinary Rules. AOH Vol. 65, No. 4, pp. 427-444.

Heirman, Ann (2014): Washing and Dyeing Buddhist Monastic Robes. $A O H$ Vol. 67, No. 4, pp. 467-488.

Heirman, Ann-De Rauw, Tom (2006): Offenders, Sinners and Criminals: The Consumption of Forbidden Food. $A O H$ Vol. 59, No. 1, pp. 57-83.

Heirman, Ann - Torck, Mathieu (2012): A Pure Mind in a Clean Body: Bodily Care in the Buddhist Monasteries of Ancient India and China. Ghent, Academia Press.

Hirakawa, Akira 平川彰 (1970): Ritsuzo no Kenkyū 律蔵の研究 [A study of the Vinaya-Pitaka]. Tokyo, Sankibō Busshorin.

Horner, Isaline Blew (1938-1966): The Book of Discipline (Vinaya-Pitaka). 6 vols. London, Pali Text Society.

Ichimura, Shohei (2006): The Baizhang Zen Monastic Regulations. Berkeley, Calif., Numata Center for Buddhist Translation and Research.

Kieschnick, John (1999): The Symbolism of the Monk's Robe in China. Asia Major Vol. 12, No. 1, pp. 9-32.

Kieschnick, John (2003): The Impact of Buddhism on Chinese Material Culture. Princeton, NJ, Princeton University Press.

Kieschnick, John (2005): Buddhist Vegetarianism in China. In: Roel Sterckx (ed.): Of Tripod and Palate: Food, Politics, and Religion in Traditional China. New York, Palgrave Macmillan, pp. $186-212$.

Li, Rongxi (2000): Buddhist Monastic Traditions of Southern Asia: A Record of the Inner Law Sent Home from the South Seas. Berkeley, Calif., Numata Center for Buddhist Translation and Research.

Liu, Xinru (1996): Silk and Religion: An Exploration of Material Life and the Thought of People AD 600-1200. Delhi, Oxford University Press.

Luo, Chongqi 骆崇骐 (1990): Zhongguo xie wenhua shi 中国鞋文化史 [The history of the culture of shoes in China]. Shanghai, Shanghai kexue jishu chubanshe.

Luo, Chongqi 骆崇骐 (2007): Zhongguo lidai xielü yanjiu yü jianshang 中国历代鞋履研究与鉴赏 [Study and appreciation of Chinese shoes in the past histories]. Shanghai, Donghua daxue chubanshe.

Luo, Chongqi 骆崇骐 (2014): Qutan Zhonghua xie shi 趣谈中华鞋史 [Discussion of the history of shoes in China]. Shanghai, Donghua daxue chubanshe.

Maes, Claire (2010-2011): One-Sensed Facultied Life (ekindriya jīva) in the Pāli vinaya: A Camouflaged Debate between Early Buddhists and Jains. Bulletin d'Études Indiennes Nos $28-$ 29 , pp. $85-104$.

Maes, Claire (2015): Dialogues with(in) the Pāli Vinaya: A Research into the Dynamics and Dialectics of the Pāli Vinaya's Ascetic Others, with a Special Focus on the Jain Other. Unpublished Ph.D. thesis, Ghent University. 
Mrozik, Suzanne (2007): Virtuous Bodies: The Physical Dimensions of Morality in Buddhist Ethics. Oxford, Oxford University Press.

Nakamura, Hajime (1985 [1981]): Bukkyōgo daijiten 佛教語大辞典 [Dictionary of Buddhist terms]. Tokyo, Tōkyō shoseki kabushiki kaisha.

Nattier, Jan (2003): A Few Good Men: The Bodhisattva Path According to The Inquiry of Ugra (Ugraparipricchā). Honolulu, University of Hawaii Press.

Schlütter, Morten (2005): Vinaya Monasteries, Public Abbacies, and State Control of Buddhism under the Song (920-1279). In: Bodiford, William M. (ed.): Going Forth, Visions of Buddhist Vinaya: Essays Presented in Honor of Professor Stanley Weinstein. Honolulu, University of Hawaii Press, pp. 136-160.

Schmithausen, Lambert (2009): Plants in Early Buddhism and the Far Eastern Idea of the BuddhaNature of Grasses and Trees. Lumbini, Lumbini International Research Institute.

Schopen, Gregory (1997): Cross-dressing with the Dead: Asceticism, Ambivalence, and Institutional Values in an Indian Monastic Code. In: Cuevas, Bryan J. - Stone, Jacqueline I. (eds): The Buddhist Dead: Practices, Discourses, Representations. Honolulu, University of Hawaii Press, pp. 60-104.

Tanaka, Yoko (2015): Embroidered Slippers in the Shōsōin Repository. In Stevenson, John - Dusenbury, Mary M. - O’Neil Rife, Ellen (eds): Color in Ancient and Medieval East Asia. New Haven, Conn. - London, Yale University Press, pp. 142-147.

Witkowski, Nicholas (2013): Pāmśsukūlika as a Standard Practice in the Vinaya. Paper presented at the Vinaya Conference, Hangzhou, China, 21-22 August.

Yifa (2002): The Origins of Buddhist Monastic Codes in China. Honolulu, University of Hawaii Press.

Young, Stuart H. (2013): For a Compassionate Killing: Chinese Buddhism, Sericulture, and the Silkworm God Aśvaghoṣa. Journal of Chinese Religions Vol. 41, No. 1, pp. 25-58.

Young, Stuart H. (2015): Conceiving the Indian Buddhist Patriarchs in China. Honolulu, University of Hawaii Press.

Yuyama, Akira (1979): Systematische Übersicht über die buddhistische Sanskrit-Literatur, Erster Teil: Vinaya-Texte. Wiesbaden, Franz Steiner Verlag.

Zamperini, Paola (2006): A Dream of Butterflies? Shoes in Chinese Culture. In: Riello, Giorgio McNeil, Peter (eds): Shoes: A History from Sandals to Sneakers. Oxford - New York, Berg, pp. 196-205. 